\title{
Effect of Room-temperature, Calcined Eggshell Reactants on Synthesis of Hydroxyapatite
}

\author{
Tea-Sung Kang*, Cristian M. Pantilimon*, and Sang-Jin Lee****† \\ *Department of Advanced Materials Science and Engineering, Mokpo National University, Muan 534-729, Korea \\ **Research Institute of Ceramic Industry Technology, Mokpo National University, Muan 534-729, Korea \\ (Received March 12, 2015; Revised May 16, 2015; Accepted May 18, 2015)
}

\begin{abstract}
Synthesis of hydroxyapatite (HA) was attempted through a room-temperature reaction of calcined eggshell with phosphoric acid. Ball-milled, calcined eggshell powder, which has a specific surface area of $31.6 \mathrm{~m}^{2} / \mathrm{g}$, was mixed with various concentrations of phosphoric acid at room temperature. The mixtures showed high reactivity and a vigorous exothermic reaction ; the reacted samples showed both $\mathrm{Ca}(\mathrm{OH})_{2}$ and $\mathrm{CaHPO}_{4}$ crystal phases. After heating at temperatures above $400^{\circ} \mathrm{C}$, an $\mathrm{HA}$ crystal phase was observed in all samples. The calcined eggshell showed a pure $\mathrm{CaO}$ single phase, while the $\mathrm{Ca}(\mathrm{OH})_{2}$ phase was only observed in the wet, ball-milled calcined powder. The degree of formation of the HA crystal phase increased as the phosphoric acid concentration and the heating temperature were increased. A mixture with $50 \mathrm{wt} \%$ phosphoric acid concentration showed a well-developed HA crystal phase after heat treatment at $800^{\circ} \mathrm{C}$, while the formation of a more intensive amorphous phase was observed in the products of the room-temperature reaction.
\end{abstract}

Key words : Biomaterials, Powder processing, Crystallization, X-ray diffraction, Hydroxyapatite

\section{Introduction}

A patite is the major mineral composing hard tissues, such as bone and dentin in the human body. The biomineralization of apatite is usually a self-remodeling process guided by osteoblast cells and proteins. Because apatite materials have high bio-compatibility, they are often called bio-materials. These materials utilize apatite mineralized on their surfaces as an interface to integrate spontaneously with living tissue. ${ }^{1-5)}$ In particular, calcium phosphate ceramic materials are an important subject in bio-material research.

Hydroxyapatite powders are mainly used as a source material to form sintered bodies and polymer composites. Certain applications depend on the HA structure, crystallinity, particle size, and morphology. ${ }^{6-7)}$ Synthesis methods for HA include precipitation, the sol-gel method, the microemulsion method, the solid-phase reaction method, the hydrolysis method, the microwave irradiation method, and many other synthetic methods. However, the three main methods (sol-gel method, precipitation method, and microemulsion method) result in the formation of non-stoichiometric products. The low crystallinity of the product material is due to experimental conditions such as $\mathrm{pH}$, temperature, or contamination of the reactants, whose ions,

${ }^{\dagger}$ Corresponding author : Sang-Jin Lee

E-mail : lee@mokpo.ac.kr

Tel : +82-61-450-2493 Fax : +82-61-450-2498 sodium, potassium, nitrate, and chloride show strong affinity with HA. Non-stoichiometric apatite and stoichiometric HA have the same crystal structures. ${ }^{8-14)}$ Even though HA has high bio-compatibility, its use as a single material for growing artificial bone is restricted, because it is a brittle ceramic. ${ }^{15-16)}$ For this reason, HA is used to prepare composite materials, such as HA coatings, for placement on titanium metal. This process has recently been studied to compensate for the short-comings of HAs. ${ }^{15-17)}$

Calcium phosphates were recently synthesized using natural calcium sources. In the studies that were conducted, several natural materials such as tuna bones, cuttlefish bones, oyster shells, cockle shells, and eggshells were used to improve the bio-compatibility. ${ }^{18-23)}$ In particular, eggshell was transformed to a pure $\mathrm{CaO}$ powder using a simple heat treatment. Calcium phosphates such as tri-calcium phosphate (TCP) and hydroxyapatite thus have been synthesized through a soft solution process using eggshell. ${ }^{21-22)}$

In this study, nano-sized $\mathrm{CaO}$ powders obtained by wetmilled, calcined eggshell were used as a starting powder. The processed powders were reacted with various concentrations of phosphoric acid solution at room temperature without any other media. The possibility of synthesizing HA at low temperature, combined with the use of low concentration phosphoric acid solutions, was thus examined.

\section{Experimental Procedure}

Washed raw eggshells were calcined in an air atmosphere at $900^{\circ} \mathrm{C}$ for $4 \mathrm{~h}$. The calcined eggshells were wet ball-milled 
to break down the agglomerated powders. The wet milling process was performed using an isopropyl alcohol solvent (IPA, 99.5\%, Daejung Chemicals \& Metals CO., LTD, Korea) and zirconia ball media for $24 \mathrm{~h}$. The volume ratio of calcined eggshell to IPA was $1: 1$. The milled powders were dried at $80^{\circ} \mathrm{C}$ for $48 \mathrm{~h}$. The main reaction for obtaining HA is induced by combining the processed powders with phosphoric acid solutions of various concentrations (10 wt\%, $30 \mathrm{wt} \%, 50 \mathrm{wt} \%)$. The phosphoric acid solutions were made by mixing D.I. water with a phosphoric acid reagent (85wt\% in $\mathrm{H}_{2} \mathrm{O}$, DC Chemical Co. Ltd.). The prepared phosphoric acid solutions were manually mixed with the processed powders at a 1:1.5 weight ratio. After mixing, all samples were completely dried at room temperature, and then the powders were subjected to heat treatment at temperatures ranging from $200^{\circ} \mathrm{C}$ to $800^{\circ} \mathrm{C}$ with a heating rate of $3^{\circ} \mathrm{C} / \mathrm{min}$ and holding time of $4 \mathrm{~h}$. The development of crystalline phases in the as-synthesized powders was determined using X-ray diffraction (XRD, X'pert-pro MPD, PANalytical, Netherlands). The morphological characteristics of the calcined eggshell before and after wet milling were determined using field emission scanning electron microscopy (FE-SEM, S4800, Hitachi, Japan). The specific surface area of the calcined and wet-milled eggshell was observed using an Automated Surface Area \& Pore Size Analyzer (Quadrasorb SI$\mathrm{Kr}$, Quantachrome Instruments, USA). The pyrolysis and synthesis behavior of the samples reacted at room temperature were monitored by a thermogravimetric analysis/differential scanning calorimetry (TGA/DSC, TG2171, Thermo Cahn Corp., USA) in an air atmosphere at temperatures up to $900^{\circ} \mathrm{C}$ with a heating rate of $10^{\circ} \mathrm{C} / \mathrm{min}$.

\section{Results and Discussion}

According to the previous study, raw eggshells before calcination display a main crystal phase of $\mathrm{CaCO}_{3} \cdot{ }^{23)}$ Calcined eggshell showed a single $\mathrm{CaO}$ crystal phase in XRD observation. This is presumed to be because the main ingredient of eggshell is $\mathrm{CaCO}_{3}$, which decomposes. However, after the wet milling process, the calcined eggshell powders showed $\mathrm{CaO}$ and $\mathrm{Ca}(\mathrm{OH})_{2}$ phases. XRD patterns before and after wet milling of the calcined eggshell are shown in Fig. 1. After milling the calcined eggshell powders, the specific surface areas of the pre- and post-wet milling powders increased substantially from $1.199 \mathrm{~m}^{2} / \mathrm{g}$ to $31.566 \mathrm{~m}^{2} / \mathrm{g}$. The change in specific surface area led to a reaction of the calcined eggshell powders with water molecules from the air or the hydroxide ions inside the IPA $\left(\mathrm{C}_{3} \mathrm{H}_{8} \mathrm{O}\right)$, allowing for the formation of the $\mathrm{Ca}(\mathrm{OH})_{2}$ phase. SEM images of the calcined eggshell before and after wet milling are shown in Figs. 2 and 3. Before wet milling, the powders showed high agglomeration; after the wet milling process, however, agglomeration significantly decreased.

When mixing the calcined eggshell powders with solutions of various concentrations of phosphoric acid ( $10 \mathrm{wt} \%$ to 50 wt\%), exothermic reactions were observed, with the amount

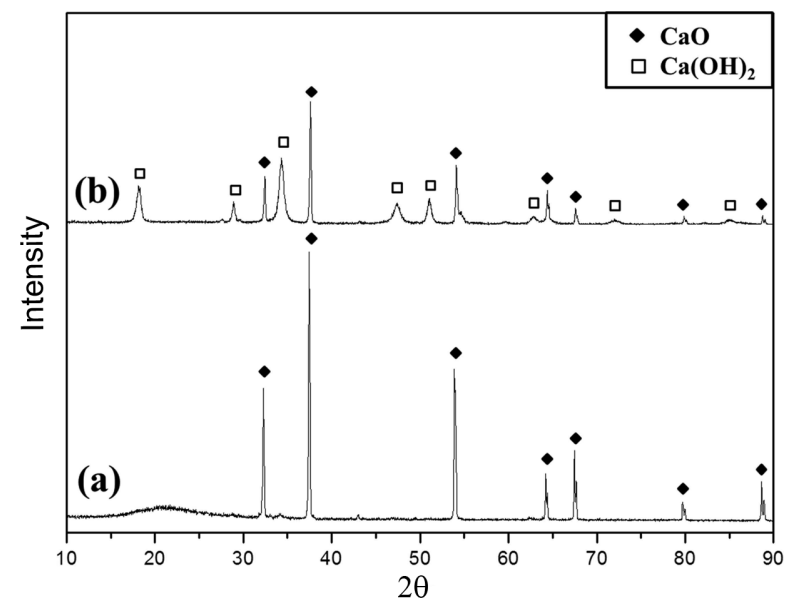

Fig. 1. XRD patterns of (a) pre-wet milling and (b) post-wet milling eggshells calcined at $900^{\circ} \mathrm{C}$ for $24 \mathrm{~h}$.

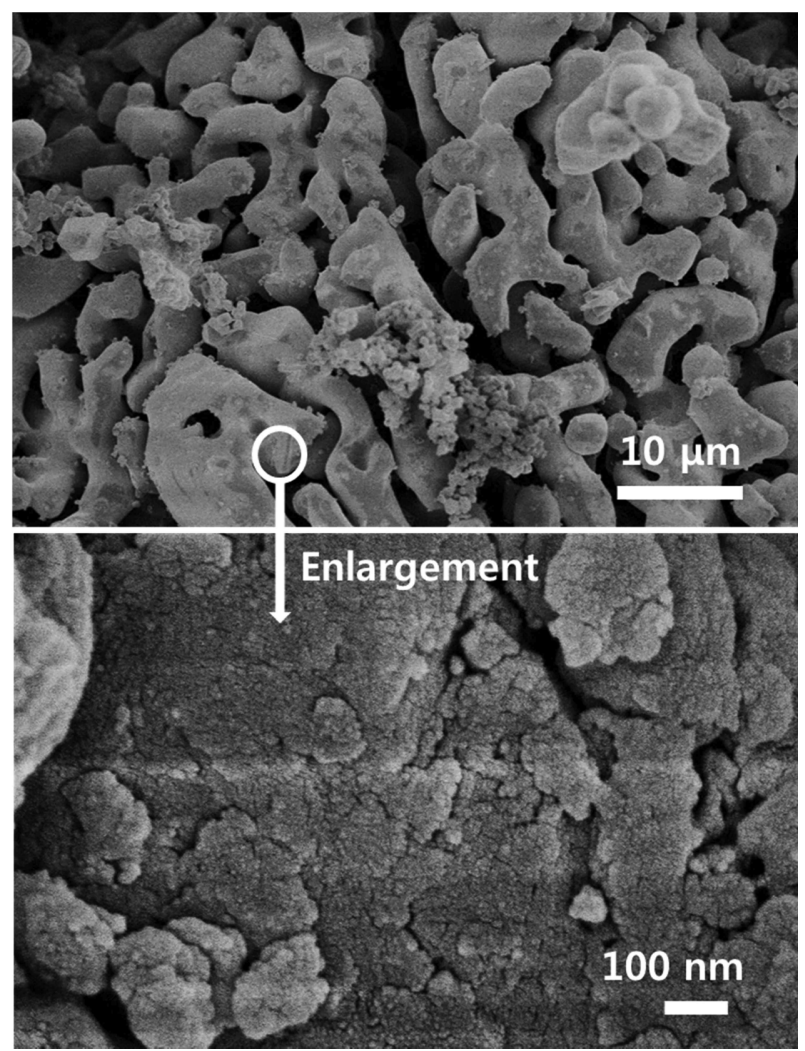

Fig. 2. SEM morphologies of pre-wet milling eggshell calcined at $900^{\circ} \mathrm{C}$.

of heat released by the reaction being directly dependent on the concentration of phosphoric acid. The results of changes in the crystal phase in relation to the reaction of the powders with phosphoric acid solutions of various concentrations and in relation to the temperature of the heat treatment are shown in Figs. 4 to 6. In the samples used to evaluate the reaction at room temperature between phosphoric acid solutions of $10 \mathrm{wt} \%$ to $30 \mathrm{wt} \%$ and calcined eggshell powders, $\mathrm{Ca}(\mathrm{OH})_{2}$ was observed as the major crystal 
phase, while $\mathrm{CaHPO}_{4}$ appears as a minor crystal phase. These results can be attributed to the low concentration of phosphoric acid solution used in the reaction; there were not sufficient phosphate ions for complete reaction with the prepared powders, and this in turn led to a reaction of the powders with the D.I. water in the solution, generating the $\mathrm{Ca}(\mathrm{OH})_{2}$ crystal phase. On the other hand, the powders reacted with the $50 \mathrm{wt} \%$ concentration phosphoric acid solution displayed $\mathrm{CaHPO}_{4}$ as the major crystal phase. All the

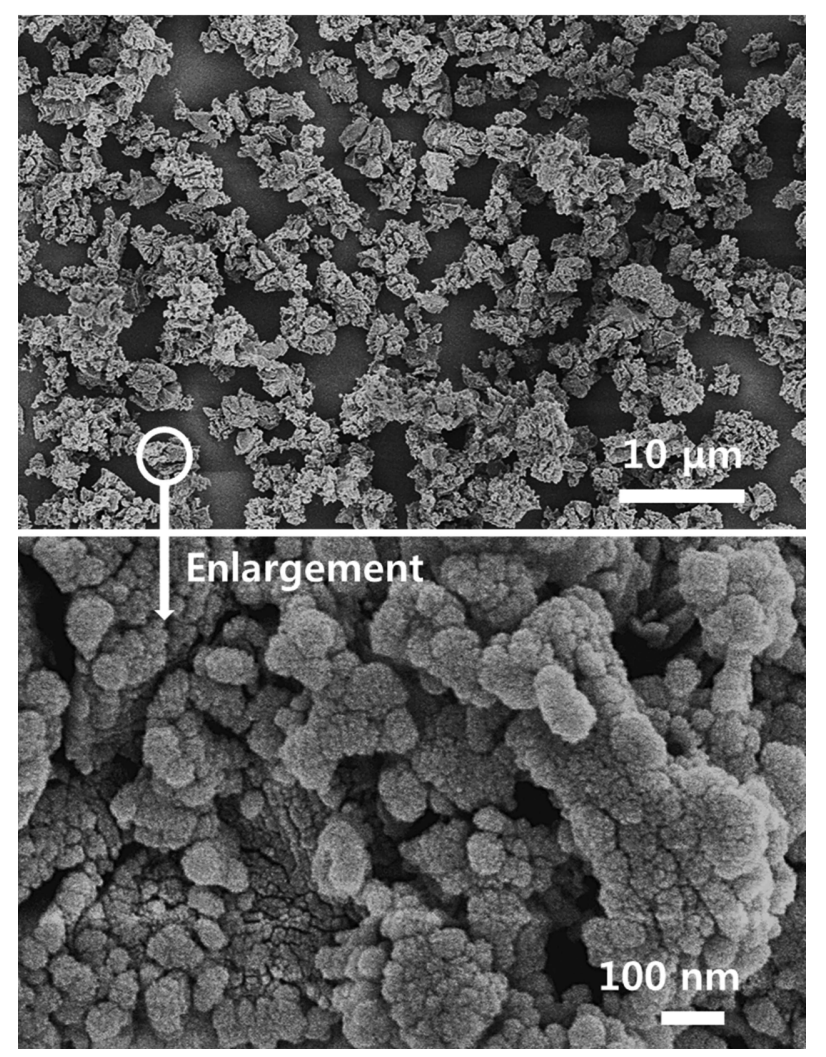

Fig. 3. SEM morphologies of wet-milled eggshell calcined at $900^{\circ} \mathrm{C}$.

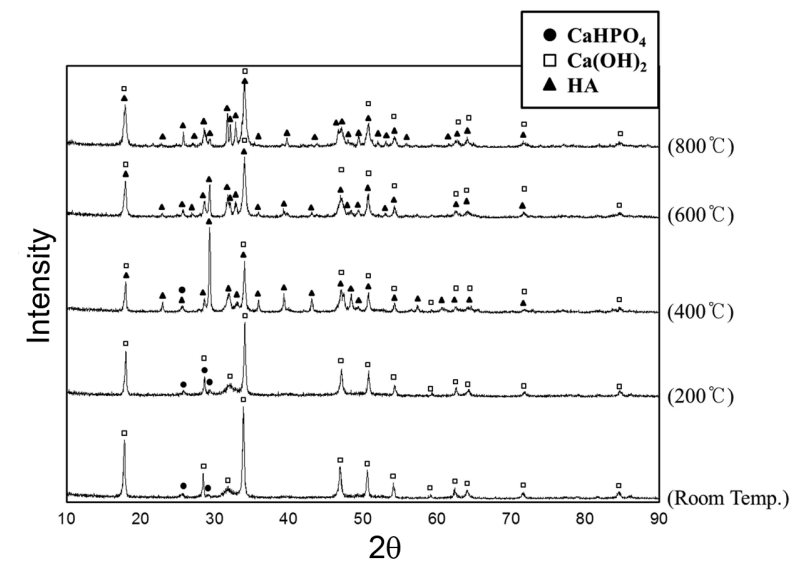

Fig. 4. XRD patterns of wet-milled calcined eggshell powder mixtures with $10 \mathrm{wt} \%$ phosphoric acid solution according to heating temperature (JCPDS Card No. : 77-0128, 72-0156, 86-1201). powders heat treated at $400^{\circ} \mathrm{C}$ displayed the HA crystal phase. The presence of the HA crystal phase increased as the temperature increased. The mixture with $50 \mathrm{wt} \%$ phosphoric acid concentration (Fig. 6) showed a relatively well developed HA crystal phase after heat treatment at $800^{\circ} \mathrm{C}$, while some amorphous phase material was observed in the room-temperature reactants.

The simultaneous TGA/DSC results of the powders reacted with $10 \mathrm{wt} \%$ to $50 \mathrm{wt} \%$ concentrations of phosphoric acid solution, heated from room temperature to $900^{\circ} \mathrm{C}$, are shown in Fig. 7. As can be seen in these results, endothermic reactions were observed, with weight reductions noticeable for temperatures in the range of $400^{\circ} \mathrm{C}$ to $500^{\circ} \mathrm{C}$ and at temperatures over $600^{\circ} \mathrm{C}$. Through an analysis of the TGA/ DSC results and the XRD patterns, it is speculated that $\mathrm{Ca}_{5}(\mathrm{OH})\left(\mathrm{PO}_{4}\right)_{3}$ is generated at these temperatures in a twostep reaction.

In the first step, $\mathrm{Ca}(\mathrm{OH})_{2}$ undergoes a decomposition phase and reacts with $\mathrm{CaHPO}_{4}$ in a temperature range of $400^{\circ} \mathrm{C}$ to $500^{\circ} \mathrm{C}$, generating $\mathrm{HA}$.

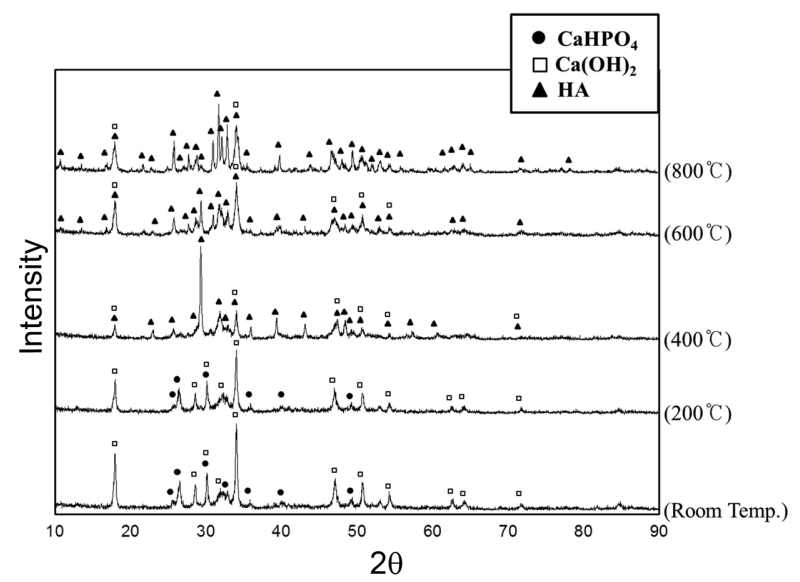

Fig. 5. XRD patterns of wet-milled calcined eggshell powder mixtures with $30 \mathrm{wt} \%$ phosphoric acid solution according to heating temperature.

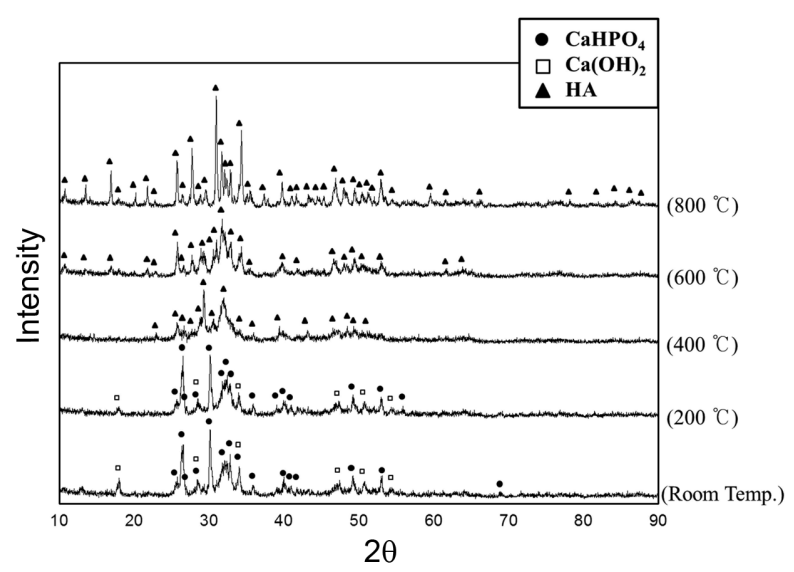

Fig. 6. XRD patterns of wet-milled calcined eggshell powder mixtures with $50 \mathrm{wt} \%$ phosphoric acid solution according to heating temperature. 


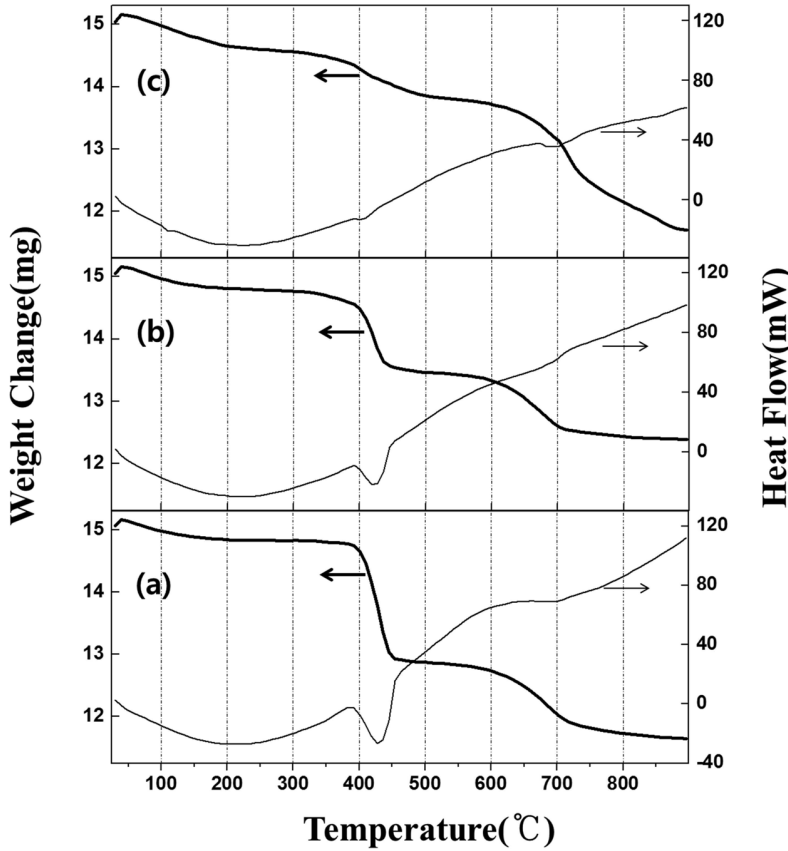

Fig. 7. TGA/DSC results for as-reacted calcined eggshell powder mixtures with (a) $10 \mathrm{wt} \%$, (b) $30 \mathrm{wt} \%$ and (c) 50 wt\% phosphoric acid solutions.

$$
\begin{aligned}
& 2 \mathrm{Ca}(\mathrm{OH})_{2(\mathrm{~g})}+3 \mathrm{CaHPO}_{4(\mathrm{~g})} \text { or } \mathrm{H}_{3} \mathrm{PO}_{4} \\
& \rightarrow \mathrm{Ca}_{5}(\mathrm{OH})\left(\mathrm{PO}_{4}\right)+3 \mathrm{H}_{2} \mathrm{O}_{(\mathrm{g})}
\end{aligned}
$$

At $400^{\circ} \mathrm{C}$ to $500^{\circ} \mathrm{C}$, in the case of the lower concentration of phosphoric acid precursor (Fig. 7(a)), an increase in weight is observed. This is the result of a higher quantity of $\mathrm{Ca}(\mathrm{OH})_{2}$ particles, which is due to the low concentration of the phosphoric acid solution. At $400^{\circ} \mathrm{C}$, the XRD pattern shows a significant decrease of the $\mathrm{Ca}(\mathrm{OH})_{2}$ peaks, which further validates the idea that these particles undergo decomposition starting at this temperature. For heat treatments of $400^{\circ} \mathrm{C}$ and above, the XRD analysis shows the presence of $\mathrm{Ca}(\mathrm{OH})_{2}$ peaks. It is assumed that the unreacted calcium components such as calcium oxide react with the humidity in the air during the $\mathrm{XRD}$ analysis process, due to their high reactivity. In addition, the TGA/DSC results showed an increase in weight at around room temperature for all samples. It is speculated that, because of the high specific surface area of the $\mathrm{CaO}$ powders, the mixtures react with the humidity in the air, producing the $\mathrm{Ca}(\mathrm{OH})_{2}$ phase.

In the second step, $\mathrm{CaHPO}_{4}$ is decomposed at a temperature of over $600^{\circ} \mathrm{C}$. While undergoing decomposition, $\mathrm{CaH}$ $\mathrm{PO}_{4}$ reacts with the unreacted $\mathrm{CaO}$ generated during the first step between $400^{\circ} \mathrm{C}$ to $500^{\circ} \mathrm{C}$ through the decomposition of $\mathrm{Ca}(\mathrm{OH})_{2}$, leading to the synthesis of HA.

$$
2 \mathrm{CaO}_{(\mathrm{g})}+3 \mathrm{CaHPO}_{4(\mathrm{~g})} \rightarrow \mathrm{Ca}_{5}(\mathrm{OH})\left(\mathrm{PO}_{4}\right)+\mathrm{H}_{2} \mathrm{O}_{(\mathrm{g})}
$$

According to the XRD patterns of the powders reacted at
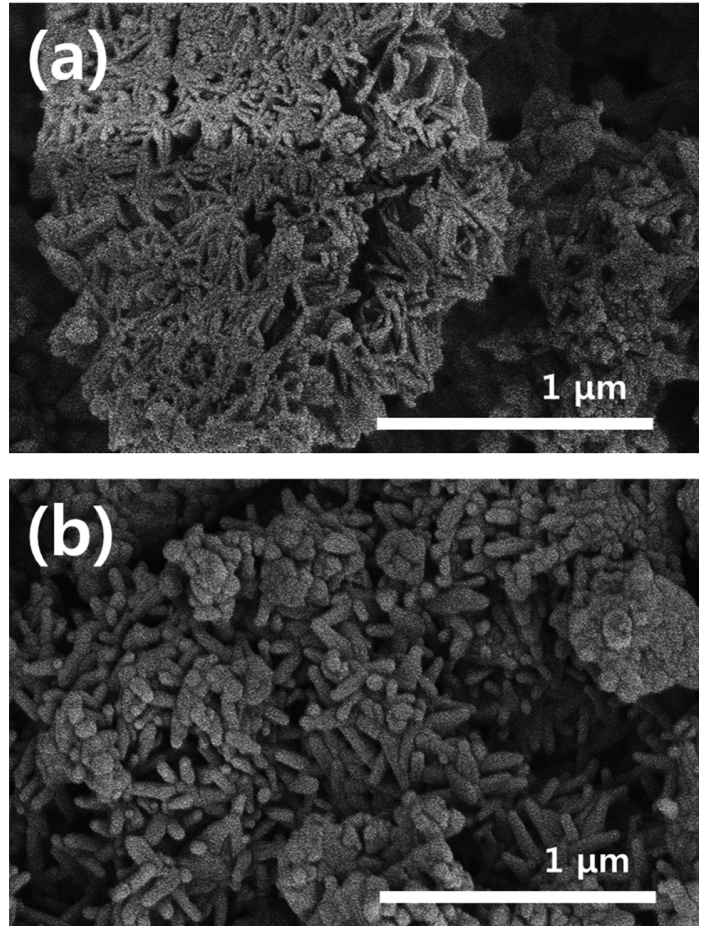

Fig. 8. SEM morphologies of eggshell powder mixtures reacted with 50 wt\% phosphoric acid solution: (a) as-reacted at room temperature and (b) after heat treatment at $800^{\circ} \mathrm{C}$.

room temperature, using higher concentrations of phosphoric acid solution can lead to the formation of more CaH$\mathrm{PO}_{4}$ than $\mathrm{Ca}(\mathrm{OH})_{2}$. The weight change of the sample reacted with the $50 \mathrm{wt} \%$ phosphoric acid solution consequently saw a faster increase at temperatures over $600^{\circ} \mathrm{C}$ than did the samples reacted with the low concentration (10 wt\% and 30 wt\%) phosphoric acid solution. $\mathrm{CaHPO}_{4}$ is not observed in the XRD patterns of the powders subjected to heat treatment at and above $400^{\circ} \mathrm{C}$. This contradicts the results of the TGA/DSC analysis, which showed that $\mathrm{CaHPO}_{4}$ should still be present in the powders at these temperatures. The reasons for this discrepancy are the fast heating rate of the TGA/DSC analysis $\left(10^{\circ} \mathrm{C} / \mathrm{min}\right)$ and also the absence of long holding time. The slower heating rate of the synthesis process $\left(3^{\circ} \mathrm{C} / \mathrm{min}\right)$, combined with the longer holding time, allow for the possibility of reaction between the $\mathrm{Ca}(\mathrm{OH})_{2}$ (between $400^{\circ} \mathrm{C}$ and $500^{\circ} \mathrm{C}$ ) or $\mathrm{CaO}$ (above $600^{\circ} \mathrm{C}$ ) and the $\mathrm{CaHPO}_{4}$, which subsequently leads to the synthesis of HA.

SEM images of nano-sized calcined eggshell powders reacted with the phosphoric acid solution of $50 \mathrm{wt} \%$ concentration at room temperature and the same powders after heat treatment at $800^{\circ} \mathrm{C}$ are shown in Fig. 8. It can be observed that the powders display both needle shaped and plate shaped particles. The XRD pattern analysis results displayed in Fig. 6 show that, at room temperature, the $\mathrm{CaHPO}_{4}$ crystal phase is formed in combination with the $\mathrm{Ca}(\mathrm{OH})_{2}$ crystal phase. Based on the XRD patterns (Fig. 6), it is assumed that the needle shaped particles are $\mathrm{CaHPO}_{4}$ 
while the plate shaped particles belong to the $\mathrm{Ca}(\mathrm{OH})_{2}$ crystal phase. In the case of the sample heat treated at $800^{\circ} \mathrm{C}$, it can be observed that the thickness of the needle shape particles increased, showing a submicron size. This increase is presumed to be caused by the merging of neighboring particles, which retain their needle shapes while the crystal phase changes from $\mathrm{CaHPO}_{4}$ to HA.

\section{Conclusions}

Wet-milled, calcined eggshell powders displayed a high specific surface area of $31.566 \mathrm{~m}^{2} / \mathrm{g}$. Due to the specific surface area of the powders, they are more prone to react with moisture in the air, and the surface powders tend to become $\mathrm{Ca}(\mathrm{OH})_{2}$. The amount of $\mathrm{CaHPO}_{4}$ crystal phase, another reactant between calcined eggshell $(\mathrm{CaO})$ and phosphoric acid at room temperature, depended on the concentration of the phosphoric acid solution. In the case of samples heat treated at $400^{\circ} \mathrm{C}$ and higher, the powder mixtures displayed a HA crystal phase. The formation of the HA crystal phase depended on the phosphoric acid concentration and the heat treatment temperature. The reaction, at room temperature, between the milled eggshell powders and the phosphoric acid solution with $50 \mathrm{wt} \%$ concentration resulted in the formation of needle and plate shaped particles. Needle shaped particles were also observed after heat treatment at $800^{\circ} \mathrm{C}$, showing an HA crystal phase of submicron size.

\section{REFERENCES}

1. T. Kokubo, "Recent Progress in Glass-based Materials for Biomedical Applications," J. Ceram. Soc. Jpn., 99 965-73 (1991).

2. L. L. Hench, "Bioceramics: from Concept to Clinic," J. Am. Ceram. Soc., 74 1487-510 (1991).

3. H. M. Kim, "Bioactive Ceramics: Challenges and Perspectives," J. Ceram. Soc. Jpn., 109 49-57 (2001).

4. C. Ohtsuki, H. Kushitani, T. Kokubo, S. Kotani, and T. Yamamuro, "Apatite Formation on the Surface of Ceravital-type Glass-ceramic in the Body," J. Biomed. Mater. Res., 25 1363-70 (1991).

5. W. W. Thein-Han and R. D. K. Misra, "Biomimetic Chitosan-Nanohydroxyapatite Composite Scaffolds for Bone Tissue Engineering," Acta Biomater., 5 [4] 1182-97 (2009).

6. C. Tsioptsias, I. Tsivintzelis, L. Papadopoulou, and C. Panayiotou, "A Novel Method for Producing Tissue Engineering Scaffolds from Chitin, Chitin-Hydroxyapatite, and Cellulose," Mater. Sci. Eng., 29 [1] 159-64 (2009).

7. S. Koutsopoulos, "Synthesis and Characterization of Hydroxyapatite Crystals: A Review Study on the Analytical Methods," J. Biomed. Mater. Res., 62 [4] 600-12 (2002).

8. Y. Torrent-Burgués, J. Gómez-Morales, A. López-Macipe, and Y. A. Rodríguez-Clemente, "Continuous Precipitation of Hydroxyapatite from $\mathrm{Ca} /$ Citrate/Phosphate Solutions Using Microwave Heating," Cryst. Res. Technol., 34 [5-6]
757-62 (1999).

9. M. H. Fathi and A. Hanifi, "Evaluation and Characterization of Nanostructure Hydroxyapatite Powder Prepared by Simple Sol-Gel Method," Mater. Lett., 61 [8] 3978-83 (2007).

10. Z. H. Zhou, P. L. Zhou, S. P. Yang, X. B. Yu, and L. Z. Yang, "Controllable Synthesis of Hydroxyapatite Nano-crystals via a Dendrimer-Assisted Hydrothermal Process," Mater. Res. Bull., 42 [9] 1611-18 (2007).

11. X. Zhang and K. S. Vecchio, "Hydrothermal Synthesis of Hydroxyapatite Rods," J. Cryst. Growth, 308 [1] 133-40 (2007).

12. S. Kannan, J. H. G. Rocha, S. Agathopoulos, and J. M. F. Ferreira, "Fluorine Substituted Hydroxyapatite Scaffolds Hydrothermally Grown from Aragonitic Cuttlefish Bones," Acta Biomater., 3 [2] 243-49 (2007).

13. A. Wang, D. Liu, H. Yin, H. Wu, Y. Wada, M. Ren, T. Jiang, $\mathrm{X}$. Cheng, and Y. Xu, "Size-Controlled Synthesis of Hydroxyapatite Nano-rods by Chemical Precipitation in the Presence of Organic Modifiers," Mater. Sci. Eng., 27[4] 865-69 (2007).

14. A. Banerjee, A. Bandyopadhyay, and S. Bose, "Hydroxyapatite Nano-powders: Synthesis, Densification and CellMaterials interaction," Mater. Sci. Eng., 27 [4] 729-35 (2007)

15. H. Monma, T. Kamiya, M. Tsutsumi, and Y. T. Hasegawa, "Comparative Study on Compaction and Sintering Properties of Hydroxyapatite Powders," Gypsum \& Lime, 208 [3] 127-35 (1987).

16. M. Akao, N. Miura, and H. Aoki, "Fracture Toughness of Sintered Hydroxyapatite and Beta-tricalcium Phosphate," J. Ceram. Soc. Jpn., 92 [11] 672-74 (1984).

17. M. Akao, H. Aoki, and K. Kato, "Mechanical Properties of Sintered Hydroxyapatite for Prosthetic Applications," J. Mater. Sci., 16 809-12 (1981).

18. I. J. Macha, L. S. Ozyegin, J. Chou, R. Samur, F. N. Oktar, and B. Ben-Nissan, "An Alternative Synthesis Method for Dicalcium Phosphate (Monetite) Powders from Mediterranean Mussel (Mytilus Glloprovincialis) Shells," J. Aust. Ceram. Soc., 49 [2] 122-28 (2013).

19. H. Onoda, M. Ichimura, and A. Takenaka, "Preparation and Lead Removal Effects of Calcium Phosphates with Sea Urchin Sells," Phosphorus Res. Bull., 24 49-53 (2010).

20. H. Onoda and H. Nakanishi, "Preparation of Calcium Phosphate with Oyster Shells," Nat. Resources, 3 [2] 71-4 (2012).

21. M. D. Kwon, S. H. Oh, and S. J. Lee, "Synthesis of B-tricalcium Phosphate by Using an Eggshell," J. Korean Ceram. Soc., 39 [11] 1103-07 (2002).

22. S. J. Lee, Y. S. Yoon, M. H. Lee, and N. S. Oh, "Highly Sinterable B-tricalcium Phosphate Synthesized from Eggshells," Mater. Lett., 61 1279-82 (2007).

23. S. J. Lee, Y. C. Lee, and Y. S. Yoon, "Characteristics of Calcium Phosphate Powders Synthesized from Cuttlefish Bone and Phosphoric Acid," J. Ceram. Proc. Res., 8 [6] 427-30 (2007). 